\title{
Distinctive HR Policies and Practices to Create a Workplace "Where Working Is a Pleasure" amid the Covid-19 Pandemic: The Organizational Culture of Publix Super Markets, Inc.
}

\author{
Bahaudin G. Mujtaba \\ Nova Southeastern University - College of Business and Entrepreneurship \\ 3301 College Avenue \\ Fort Lauderdale, FL. 33314-7796. USA. \\ E-mail: mujtaba@nova.edu
}

Natalie F. Mesa

Nova Southeastern University

E-mail:nm1178@mynsu.nova.edu

Shannon McGee

Nova Southeastern University

E-mail: sm3860@mynsu.nova.edu

Sherwayne O. Mears

Nova Southeastern University

E-mail: sm3540@mynsu.nova.edu

Fernando S. Moncada

Nova Southeastern University

E-mail: fm556@mynsu.nova.edu 


\title{
Macrothink
}

International Journal of Human Resource Studies

ISSN 2162-3058

2020, Vol. 10, No. 4

Received: Sep. 5, $2020 \quad$ Accepted: Sep. 30, 2020 Online published: Oct. 27, 2020

0.5296/ijhrs.v10i4.17888ＵRL: https://doi.org/10.5296/ijhrs.v10i4.17888

\begin{abstract}
Publix Super Market is relentlessly committed to creating employment opportunities for the communities it serves, especially in the face of the Covid-19 pandemic. Amid ever increasing exogenous pressure, Publix has anchored itself in its world-class Human Resource Management, e.g., staffing protocols, performance management, and employee-management relations. Based on research as well as the personal work experiences of the authors with this organization, this paper and case study offers an in-depth view of how Publix has positioned itself - and remains positioned as - one of the top companies to work for in the United States. Rather than view HR as a cog in its operational engine, Publix holds its HR department as a strategic partner. This has been instrumental in maintaining a finger on the pulse of staff's needs and creating a nurturing culture that champions every professional. Publix is not only a place where 'shopping is a pleasure,' but where working is a pleasure also.

More than 150 years ago, the Civil Rights Act of 1866 affirmed that U.S. citizens are entitled to equal protection under the law. Over 50 years ago, the passing of the Civil Rights Act of 1964 outlawed discrimination. However, despite over a century of legislation and activism, discrimination remains a pressing issue plaguing America today. Despite racial turmoil that afflicts our society, Publix has announced they will not stand for injustice by emphasizing, "Let's end the injustice. Let's stand together." Publix has made a \$1 million contribution to the National Urban League affiliates across the Southeast, as they continue to support their civil rights efforts.

Publix offers its associates career growth, and the necessary training for equitable promotional opportunities for all their diverse employees. Furthermore, it invests in its associates' health, with a benefits package that encourages wellness, smoking cessation, and provides primary care, vision, and dental plans. Using a qualitative process based on personal experiences and documented literature, this case study will guide you through some of Publix's hallmark human resource policies, how the company has embraced them, and how it works daily to encourage and incentivize its associates' career growth.
\end{abstract}

Keywords: publix, organizational culture, George Jenkins, distinctive HR practices, Covid-19 


\section{Introduction}

It has been said that leaders can lead or influence others orally by speaking about their vision, in a written format by specifying the end goals through general means or a step-by-step format, and/or simply by being a good example. Of course, the best leaders and successful firms communicate the same message effectively through integrated marketing communication (IMC) orally and in writing, while also "practicing what they preach" in order to stay consistent with their core messages to all stakeholders. While Publix employees, managers and leaders may not always orally put themselves on a pedestal or write extensively about their best practices, they certainly are leading by being a good example of how an organization should be operated as they are regularly rated by external authorities (such as Fortune Magazine) to be one of the best places to work in the United States of America. So, our research questions for this qualitative, case study, is:

What are the specific and distinctive human resource practices that have helped Publix managers and employees to create an organizational culture where working and shopping are a pleasure?

We believe Publix employees, managers and executives practice what they write in their mission statement and what they promise in a socially responsible manner. As such, in a written format, we will try to make a case study of Publix's best practices, organizational cultural elements and strategic human resource management policies that have contributed to their success over the past seven decades. Let us start by better understanding the background and personality of the company's founding leader, Mr. George W. Jenkins.

\section{Company History}

George W. Jenkins, the late founder of Publix, was born on September 29, 1907, in Harris, Georgia. At the age of 17, young Jenkins relocated from Georgia to Tampa of Florida and began working as a produce clerk in a Piggly Wiggly grocery store. Due to his commitment and hard work, Jenkins was promoted to a management position within a couple of months. Shortly thereafter, he was entrusted with managing Piggly Wiggly's largest store, which was located in Winter Haven. He proceeded to work as a manager from 1926 to 1930. In 1930, he resigned from Piggly Wiggly to start his own grocery store.

On September 6, 1930, Jenkins founded Publix Food Store in Winter Haven, Florida. In 1945, he acquired a warehouse and 19 All American grocery stores from the Lakeland Grocery Company. He began replacing these smaller stores with large supermarkets. He relentlessly expanded Publix, bringing its standard of clean stores, friendly service, and quality merchandise to customers throughout Florida. Over the years, through effective training and development of their employees and managers, Publix has evolved from an ambitious venture into a Fortune 500 company, which demonstrates that strategic investments in human capital makes a huge positive difference in making a company a great place to work (Great Place to Work, 2019; Aragón-Sánchez, Barba-Aragón \& Sanz-Valle, 2003). The business has been named one of Fortune's 100 Best Companies to Work For in America for over 21 consecutive years. Publix has supermarkets in several different states across the U.S. and more than 
200,000 employees. "It's a tremendous honor to be recognized as one of the world's most admired companies, let alone to be a part of this prestigious group for the past decade," said Rich Hume, CEO of Tech Data, in a statement (Owens, 2019, para. 5).

Publix's mission is to remain a premier quality food retailer in the world. Towards that end, the company is passionate about customer value, reducing waste, promoting dignity, and job security. Publix devotes itself to the highest standards of stewardship for stockholders, and it promotes responsible citizenship through community programs to the areas it serves.

At Publix, the human resources department is a strategic partner and this is perhaps an influential variable that helps to make them a powerful and competitive organization (Acosta, 2018; Publix, 2019; Publix Power, 2014; Ozolina-Ozola, 2014; Tkaczyk, 2016; Testa, 2001; Tessema, Ready, Embaye, 2013). What separates Publix from many other companies is that its "associates" are invested in the company-literally and figuratively. One of the challenges faced by many supermarkets is sustainability of their operations through committed and productive employees. What makes Publix sustainable is that "baggers, meat cutters and bakers are the company's largest collective shareholders." Purchasing stocks at Publix is an exclusive benefit held by associates, who have maintained continuous employment for at least one year. This long-term investment makes its associates Publix Stockholders and cements their commitment to their company's success. The idea behind this exclusive purchasing power is to boost employee commitment and engagement. To further promote employee engagement, associates are taught to embrace the Publix '10 foot 10-second' rule. All associates are to greet customers within 10 seconds of the customer being within a distance of 10 feet. Rules like the aforementioned have enabled Publix to remain the No. 1 supermarket for customer satisfaction year after year. As owners of the company, Publix associates have access to a highly specialized human resources team that takes pride in training, developing, and continually enriching its partners' knowledge.

Over the years, Publix has grown its retail footprint, revenue totals, and staff numbers. This has been fuelled by an HR department that has broadened its roles beyond traditional employee welfare programs and administrative duties. The HR Department is built upon a diverse team of associates, including Associate Relations, Associate Services, Compensation, Diversity, Employee Assistance Program (EAP), Employment Office, Education and Training Development (ETD), as well as Labor Relations and Policies. Publix places emphasis on empowerment and continuous learning, while providing an online platform through which its associates receive training. The Associate Relations department is tasked with architecting and building upon modules that ensure Publix associates' understanding of its policies on harassment, misconduct, and diversity. The HR department has also encouraged employee participation in corporate social responsibility (CSR). The Associates Services team is a living and active extension of Mr. Jenkins' passion for community outreach. The Associate Services team spearheads Publix's United Way campaign yearly, including setting an annual contribution goal, ensuring employee engagement, and developing innovative initiatives to give back to the community. By awarding departments that raise the largest contribution for the campaign, the Associate Services team can effectively engage employees and reward commitment to community service. Publix has been able to integrate CSR in its core values 
and practices throughout its retail stores across the U.S. Generally, employees prefer to work in companies that promote their values and align such importance in their core operations.

Publix offers an exceptional benefits package that is managed by its Compensation Department. This includes medical benefits, tuition reimbursement, and a company-matched retirement plan, which extends itself to part-time employees. The company has a voluntary turnover rate of 5 percent, which is unparalleled in an industry with a 65 percent average. The Employment Office works efficiently to provide associates the necessary information to expand their knowledge base towards promotions. They publish employment opportunities, schedule interviews, and walk their associates through mock interviews to maximize their odds of success. Buttressed by a world-class Employment Office, Publix has become the largest employee-owned company in the world.

In addition to the benefits detailed above, Publix acknowledges its employees with a broad swathe of awards. For example, twelve managers were recognized for their leadership and dedication and received the President's Award-named after the later founder George W. Jenkins. Other awards include the Customer Service Award for Excellence, Safe Drivers Award, and Milestone Service awards. As a company, Publix has received numerous top-tier awards celebrating virtually every touchpoint of its business operation. From 1998-2020, Publix has been regularly named as one of Fortune's "100 Best Companies to Work For." Publix has been rated "Highest in Customer Satisfaction with Supermarket Pharmacies," eight out of the last ten years by J.D. Power. Finally, Publix ranked No. 2 among the Top Companies for Social Responsibility by Harris Poll (2017). These awards illustrate how Publix is not only a leader within its industry, but also a great place to work, one that is inclusive, socially minded, environmentally conscious, and committed to giving back to the communities it serves.

\section{Inclusion and HR Practices at Publix}

In terms of inclusion, Publix has developed intercultural competencies among its employees through the assembly of cross-cultural teamwork as the principal method of job design and interaction (Publix Supermarket Committed to Diversity, 2020). Employee's daily socialization and interactions expand their perspectives concerning differing beliefs, values, and cultural backgrounds. To promote inclusion throughout the workforce, Publix hosts an initial mandatory orientation for its new hires. This orientation introduces the company culture and a pivotal point of revealing new hires to the diversity that exists. The hope is that the new team learns of each other's ideas and hopes for their future.

Publix recognizes the diversity and embraces that its product line must also represent the community's diversity. Publix's commitment to diversity emerged in South Florida with the opening of Publix Sabor (Blank, 2011). Bright colored panels and a colorful logo welcomes the new Publix Hispanic-themed supermarkets in South Florida. Publix Sabor cooks 50 house prepared meals, inspired by chefs with backgrounds originating from the Caribbean, South and Central America. The idea is to cater to its customers' food preferences. The new markets sport ice cream and juice bars to emulate the bodegas that Hispanics frequent in their home countries (Blank, 2011). Furthermore, Publix encourages diversity through its diverse 
mainstream suppliers, which grants the company the ability to meet its varied customers' demands. As CEO Todd Jones stated "With over 220,000 associates, we benefit from being an inclusive company made up of individuals who look and think differently, with backgrounds from around the country and around the world" (Publix Supermarket Committed to Diversity, 2020).

HR practices serve as guidelines for practicing and prospective HR professionals. These guidelines are adopted universally, function as regulations delineating how to manage organizational personnel, and provide a foundation for the creation of a cordial relationship. Categorically, they are classified as the best fit and best practices. Best fit acknowledges that to add value, the policies should align with a business's strategy, i.e., concentrating on both the needs of the employees and the organization (Rose, 2019; McFarlens and Copper, 2009; Christopher, Payne \& Ballantyne, 1991; McTaggart, 2007). HR leverages best practices in spearheading the company to attain maximum competitive advantage regardless of its organizational setup (Mujtaba and Johnson, 2016). Based on the academic reflections and writings of previous authors and our own research and experience with the company, this paper seeks to evaluate the overview of HR practices at Publix, highlighting their best practices and comparing their policies and practices across the industry.

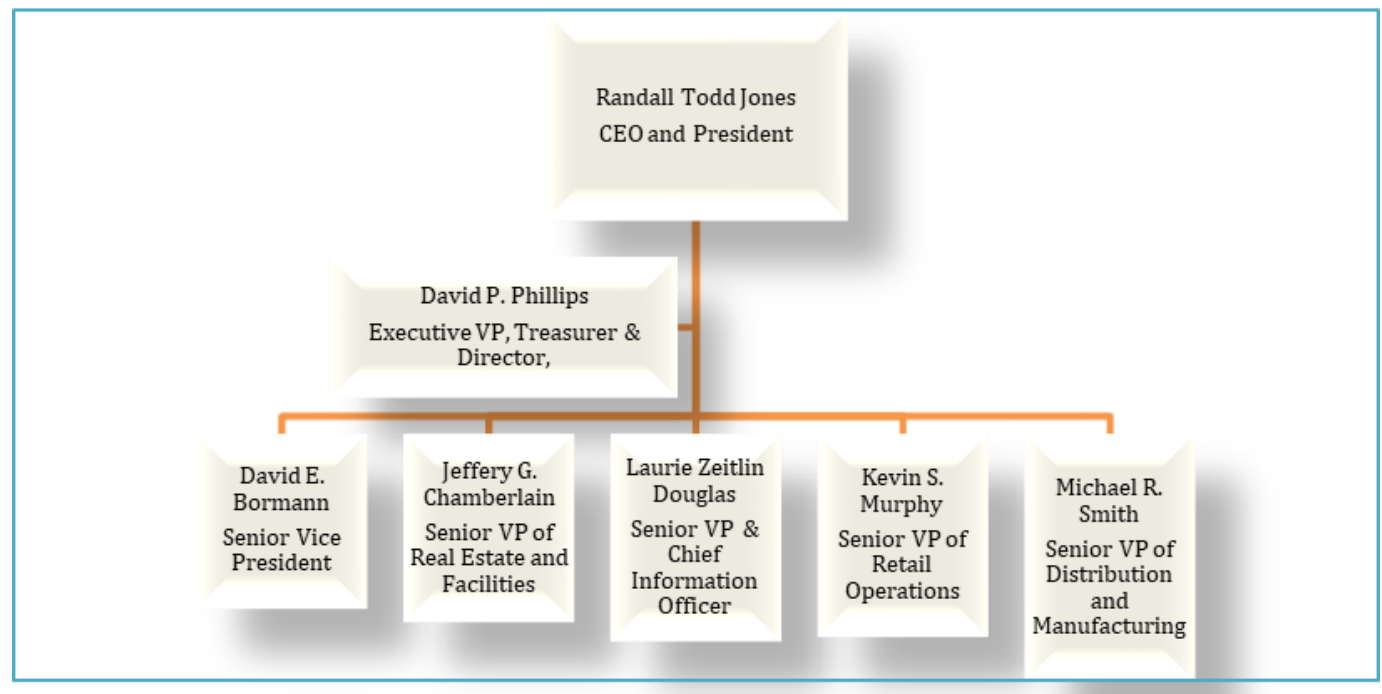

Figure 1. Publix Corporate Leaders (Publix Facts, 2020)

Publix Corporation is a private, employee-owned American supermarket retailer. Publix is headquartered in Lakeland, Florida, and traces its roots to 1930 in its Founder George Jenkins (Harrison, 2018). As of 2020, Publix has around 1252 stores spread across the United States, and is one of the largest grocery chain stores (Publix Facts and Figures, 2020). As can be seen from Figure 2, most of the stores are located in Florida, followed by Georgia, Alabama and North Carolina. 


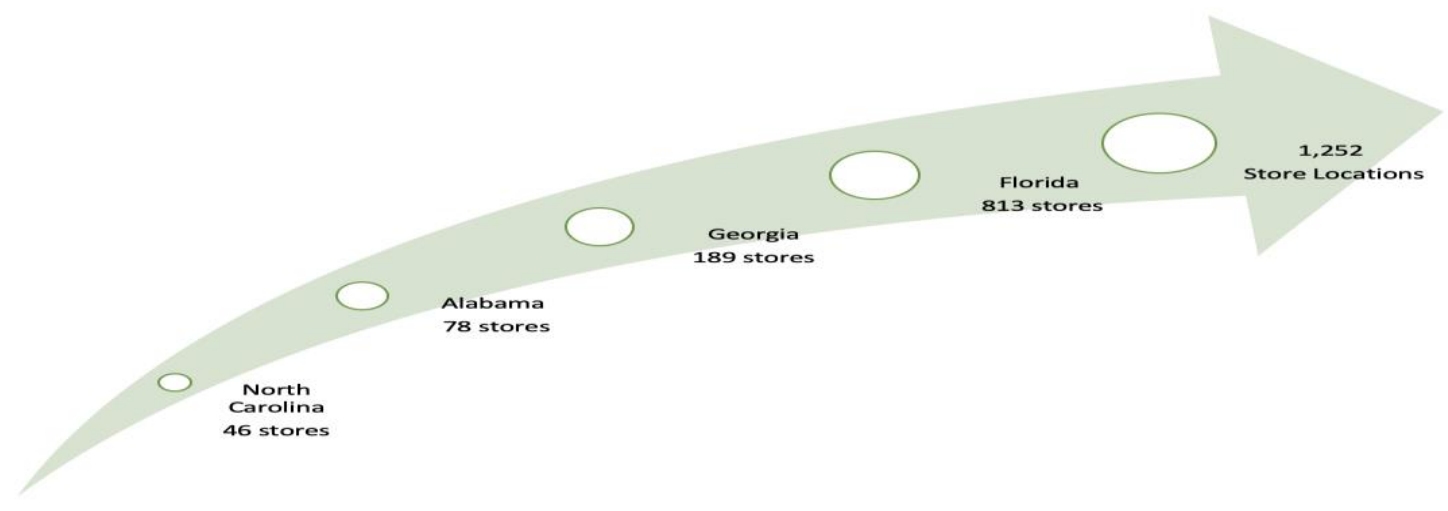

Figure 2. Publix Stores

Source: Authors' creation

The organization's diversification into the health and beauty care sector fueled its global recognition, being named among the best companies by Fortune magazine in February 2020 (Fortune, 2020). Publix has continuously been recognized on countless "Best of" lists, winning multiple awards for its long term consistency in employee and customer fulfilment. The HR department is a mission-critical component of each Publix location and vital for the overall performance of the company. The growth of the company in terms of retail stores, employees, and sales is greatly attributed to HR for its effectual employee welfare and administrative rules.

\section{Hiring and Job Security}

In today's ever-competitive retail ecosystem, employees have become an organization's most essential asset. As the source of a company's competitive advantage, it has likely never been more crucial to attract, develop, and retain the finest talent. To achieve this, management encourages, motivates, and makes employee needs an integral component of the company. Most modern organizations actively conceptualize, introduce, and calibrate measures to maximize outcomes during the recruitment, selection, and orientation process. Publix has consistently built and maintained an efficient work culture, thereby putting the company on the competitive spectrum amongst other leading players in the arena, the likes of Richmond and Wal-Mart. Publix serves clientele from diverse backgrounds, across cultural, ethnic, and socioeconomic strata. To enhance inclusivity, they recruit diverse employees, regardless of their gender, religion, or racial backgrounds. Like many other firms like American Express and the SAS Institute who are recruiting and retaining a diverse workforce, Publix fosters cultural diversity and inclusion by promoting cross-cultural competence in its workplace (Delapenha, Espinosa, Fabre, Lemon, Gibson, and Mujtaba, 2020). This focus of cross-cultural competency has strengthened diversity and inclusivity throughout the organization. They achieve this by encouraging their employees to participate in Corporate Social Responsibility (CSR) throughout their communities.

Additionally, the company has had minimal layoffs and resignations. Despite regular activism 
towards equity in the workplace, some companies are inclined to hire from a particular gender or race based on the presumption that it will boost their sales or with the end of promoting "their own." Despite the Civil Rights Act of 1964 outlawing discrimination based on race over 50 years ago, racism is still predominant and present across the United States. People of color are often discriminated against and associated with technical, low-waged, employment. At the same time, their White counterparts are less likely to be discriminated against and more readily securing well-paying, white-collar positions when competing with diverse candidates that possess equivalent qualifications.

\section{Cost Management}

Despite the vast spread of Publix outlets and over 200,000 employees, the HR department over the years has excelled at incentivizing employees via compensation and benefits. Beyond rewarding performers to motivate and retain employees, all employees that put in 1000 working hours per year receive an $8.5 \%$ addition to their total pay-in Publix stock-as a token of appreciation for their commitment throughout the fiscal year (Mujtaba and Johnson, 2016). For some small and start-up companies, effective employee appraisals and rewards are unheard of in today's environment due to lack of resources or experience on the part of the founders (Mujtaba, 2014). In such places, as personally experienced by several of the authors of this case study, employees satiate their needs with inadequate salaries, while profits are distributed amongst the top management and shareholders in the form of dividends. With these kinds of norms, good employee retention is virtually impossible since most will quit after they secure jobs with better employment terms. Via intrinsic to extrinsic drivers, Publix has bucked the trend.

\section{Training Employees}

Publix carves out funds for regular internal training. These continuous trainings are essential for employees to accelerate their career trajectory and secure upward job mobility consideration. Training helps fill emerging skill gaps and optimize employee productivity, while reducing attrition. In line with the ever-changing technology, employees must undergo regular training to keep them updated on the latest technological developments. This is key in their delivery of excellent service to customers. Rather than outsourcing or always hiring from outside, Publix has had a culture of promoting employees from within based on their qualification, seniority, performance, and goals (Harrison, 2018; Mujtaba and Johnson, 2016). Most companies are not willing to incur costs in developing and maintaining top employee training programs. For instance, in case of a skill gap, outsourcing would be considered as a primary option. Other strategies include layoffs and replacements of employees with the ones that have already acquired the skill outside. When it comes to promotions, some companies poach employees from other well-performing companies for seniority positions instead of grooming their own through a comprehensive succession planning and development program. 


\section{Employee-Owned Corporation}

Publix is ranked as the most expensive employee-owned company in the United States. The company's stock is limited only to the company's board of directors and their current employees. The stock transfer is regulated by the Employee Stock Ownership Plan (ESOP), which contains distinct provisions prohibiting stock transfer to the general public without prioritizing members of the company (Michael, 2017). Ensuring that the stock transfer is in-house adds a great benefit to employees, while increasing profit margins.

Adopting a people-first management style has enabled the retention of many employees, given they feel they are - by right-inclusive in the company. With a particular focus on its employees, the company has received national recognition as a top player in many metrics. About $99.4 \%$ of associates are owners of an individual stock at the Publix Corporation (Harrison, 2018). Employees enjoy an exclusive option to invest in the company to make their retirement life a little better. Such is a rare case in many other corporations where the stocks are entirely owned by companies' Board of Directors, the general public, and/or the government. This limits employees to production and workforce entities in the company.

\section{Healthcare Benefits}

Healthcare is an essential need for every individual. Access to affordable healthcare plans is a dream come true for every employee as it increases one's wellbeing and decrease stress (Tran, Tran, Nguyen, Mach, Phan, and Mujtaba, 2020), considering the high cost of medical services in the U.S. due to the emergence of numerous illnesses such as the Covid-19 infection. Publix has managed to retain and attract employees by their enticing health coverage plan. For a minimum of 29 working hours a week, every employee is eligible for $73 \%$ of company-paid health coverage, with an addition of $65 \%$ coverage for their dependents. According to the Saving America Workers Act (SAW), employees must work a minimum of 40 hours per week to be eligible for health care coverage from their respective companies with regards to the Affordable Care Act (Mujtaba and Johnson, 2016). To cut on cost, some companies deliberately exclude the health care providers' care package in their employment contract forcing their employees to dig into their pockets to pay for health care services.

\section{Organizational Culture}

Publix has enacted a stakeholder theory to management whereby the employee is elevated to the position of shareholder and owner. By doing so, employees work with minimal supervision since they assume the roles of management and are effectively incorporated into the leadership responsibility as owners of the company. Publix adopted open-door policies whereby managers and employees worked on concepts related to Quality Improvement Process (QIP) and Work Improvement Now (WIN) philosophies; as such, goal accomplishment and operational excellence is an ongoing personal process for each manager and employee. Each employee is mutually accountable for their responsibilities and roles at the company (Mujtaba and Johnson, 2016). This methodology drives the ongoing improvement of employees for the betterment of the company and, as shareholders, their 
share value. For companies where the manager or HR department is too controlling, productivity can be low since employees' performance is heavily dependent on rigid infrastructure.

Publix continues to enjoy positive sales growth and increases in their profit margins, which is grounded in top-tier HR practices that are the backbone of their organizational structure. They directly impact its day-to-day operational performance and serve as a launchpad for expansion, providing a bedrock to build upon amid the highly competitive dynamics of the environment. Such is attributed to their effective HR practices, coupled with favorable employee culture, and stable working environment. With the multiple policies that Publix has adopted, notably being employee-owned, it has managed to attract and retain many employees who benefit positively with the favorable employment terms at the corporation. The growth of the company in terms of retail stores, employees, and sales is greatly attributed to the department for its effectual employee welfare and administrative rules. Employees tend to be more productive when they are engaged, acknowledged and appreciated (Mujtaba, 2014).

\section{Distinctive HR Policies and Practices}

Human resource management practices were not originally perceived as providing an economic benefit to a company. Traditionally, when speaking about assets that add value to a company, technology, equipment, and facilities are at the forefront. However, staffing, employee training, employee benefits, amongst other HRM practices have become a significant source of income and savings for the corporation. As can be seen from Figure 3, there are a number of valuable benefits that are offered to Publix employees which have made the company a great place to work over the past three decades. Of course, the figure only mentions a limited number of benefits which employees want and appreciate.

Besides offering competitive benefits, we know that good HRM practices are directly correlated to increasing employee morale and, correspondingly, resulting in greater customer satisfaction (Mujtaba, 2014). By overseeing the human resource environment, employers are given the opportunity to influence their associates' performance and remain a competitive entity in the market. There are four dimensions to HRM practices a company must meet to thrive in the growing market, (i) managing the human resource environment, (ii) acquiring and preparing human resources, (iii) assessing and developing human resources, and (iv) compensating human resources (Hollenback et al., 2019). As a company, Publix has repeatedly refined its HRM practices to ensure its employees feel respected and view their employment as a long-term investment in their future. As a result, customer satisfaction at Publix continues to grow, and the Publix brand is renowned nationwide. 


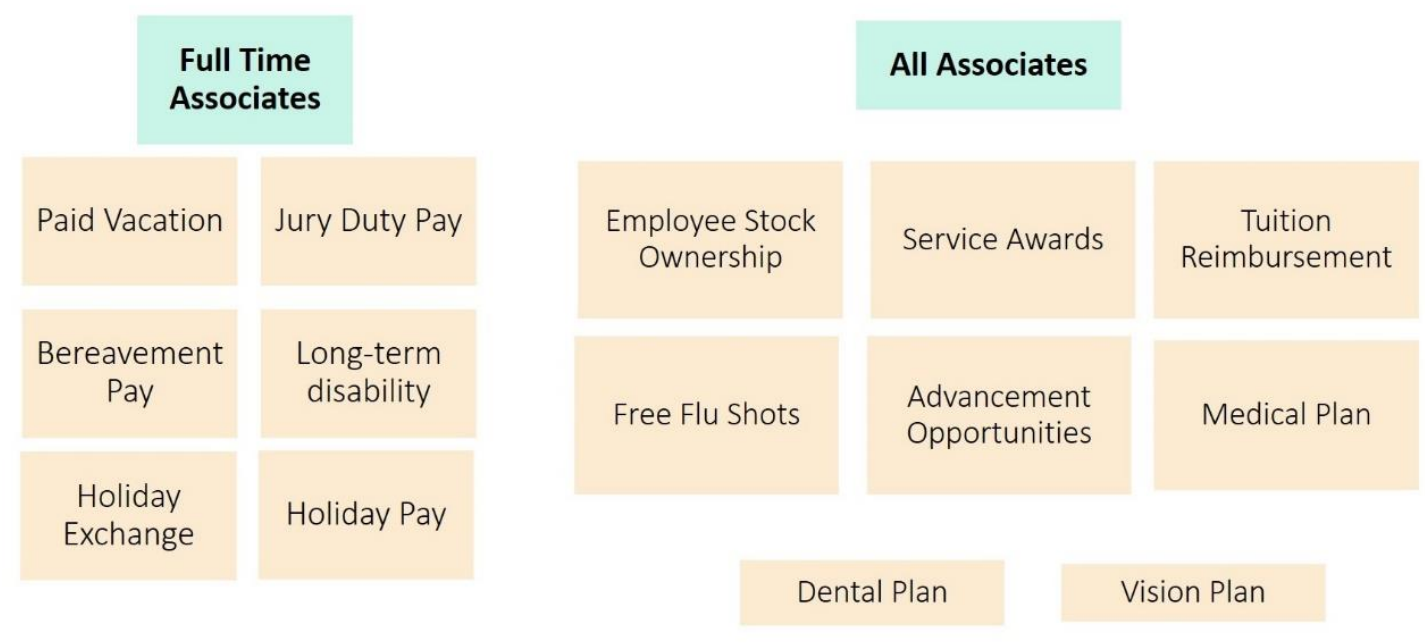

Figure 3. Publix Employee Benefits

(Source: Publix Facts, 2020; www.publix.com)

\section{Life Inspired}

Life.Inspired is a wellness program instituted by Publix for its associates. The program is focused on emphatically meeting its four pillars of wellness: eat right, exercise, quit tobacco, and achieve overall well-being (Publix Asset Management Company, 2020). Employee Wellness Programs (EWPs) are integral to positively and sustainably changing behaviors that could result in serious health issues in the near future. These programs are preventative in nature, and often seek to target specific health risks (Hollenback et al., 2019). Through their EWPs, Publix has advocated for the health of its associates and worked actively to promote healthy living.

One manner in which Publix endorses overall well-being is by offering free flu shots for their employees, during the flu season to mitigate the spread of the flu. Flu vaccinations are free to all Publix Associates during the months of August through February (Publix Asset Management Company, 2020). By visiting Publix Pharmacy associates can conveniently be administered their vaccine. Publix's goal for overall well-being extends itself to associates family members living in their household. These family members are able to receive their flu vaccine at a discounted price of \$36, compared to the customer pay of \$44 (Publix Asset Management Company, 2020). Furthermore, so that associates can avoid long lines at the pharmacy, they are given a specific day in which they are administered their vaccines in the break room without any interruptions.

\section{Tobacco Cessation}

Publix meets its commitment to tobacco cessation, through its Tobacco Cessation Program for Blue Cross Blue Shield plan members (Publix Asset Management Company, 2020). Under their healthcare benefits program, associates are offered Chantix at a reduced price, and a free GET QUIT support program (Publix Asset Management Company, 2020). The retail price of Chantix is $\$ 539$ dollars for one box, according to GoodRx (GoodRx, 2020). 
With a coupon offered by the company, the price of Chantix is reduced to $\$ 444.77$ per one box (GoodRx, 2020). With these figures we can objectively look at the negotiations that Publix made as an employer, to ensure their patients are more likely to achieve tobacco cessation. Publix associates are guaranteed a 30-day supply of Chantix at a $\$ 12$ copay for a total of six months per calendar year (Publix Asset Management Company, 2020). Publix not only seeks to encourage smoking cessation, it also recognizes that this decision is difficult. Even if a patient is unable to meet their goal of tobacco cessation goals, they can begin the process once again the next calendar year at the same discounted price. As an employer, Publix's GET QUIT program institutes a personalized step-by-step guide for its employees to begin quitting their tobacco use (Publix Asset Management Company, 2020). Publix associates are given a toll-free hotline in which they are provided a coach, to motivate them through this process. Their progress is tracked via a personalized website, and advice is offered to associates to help them avoid smoking recidivism.

\section{Employee Wellness}

As part of inspiring its associates to exercise, Publix invites all its employees to participate in their sponsored runs and walks. Some of the scheduled runs for this calendar year included the Publix Savannah Women's Half \& 5K, BHM 26.2 Marathon, Half Marathon, Marathon Relay, 5K and Fun Run, and the Space Coast Marathon and Half Marathon (Publix Asset Management Company, 2020). These runs offer a special occasion for the company to come together and grow as a team, in an environment that promotes a healthy lifestyle. As part of their Eat Right campaign all associates are provided with health, wellness, and educational resources to make better dietary choices.

Publix provides a quick link for its associates to locate fresh fruits and vegetables that are in season, including tips and nutritional recipes they can try at home with ingredients located at their fingertips. Through Aprons Simple Meal Recipes, associates have access to quick and easy recipes that they can try at home that are Carb Smart, Gluten Free, Heart Smart and Lacto-Ovo-Vegetarian friendly (Publix Asset Management Company, 2020). Ultimately, Publix has established an active Employee Wellness Program, which provides ongoing support and health education resources to its employees (Hollenback et al., 2019).

\section{PROFIT Plan, 401(k) SMART Plan, Employee Stock Purchase Plan}

Profit sharing and ownership has been a booming topic of conversation in corporate America. Profit sharing has the advantage of motivating employees, to embrace the thought process of an owner (Hollenback et al., 2019). This expands the perspective of employees, to think beyond their job description. Employees begin to address what they feel the company requires to work efficiently and effectively. Due to the fact that profit sharing does not alter base pay, it allows more flexibility to owners during economic downturns. Although profits may decrease, the company does not have to depend on layoffs to decrease labor costs (Hollenback et al., 2019). An Employee Stock Ownership Plan (ESOP) is an employee-ownership plan that provides employers certain tax and financial advantages when stock ownership is granted to employees (Hollenback et al., 2019). 
Publix began its ESOP in 1975. Referred to as the Publix Employee Stock Ownership Trust (ESOT), it is a contribution plan that invests predominantly in Publix stock (Mujtaba and Johnson, 2016). Associates can take part in the ESOP simply by being a Publix employee. After one year of employment with Publix, associates are eligible to become a participant in PROFIT Plan. Participants must have completed 1000 hours in work, within a year, to officially qualify for eligibility. In the PROFIT Plan Publix is responsible for contributing to the company stock each year. The Publix board of directors is held accountable for determining Publix's contribution each plan year which runs from January 1 through December 31. As a result, employees take pride in their work as they know that the company's prosperity has a direct impact on their financial and career growth.

Publix seems to strategically be boasting their Employee Stock Purchase Plan. As part of the Employee Stock Purchase Plan, dividends are paid directly to associates. The company offers individuals the opportunity to purchase stock in an "individual, joint, or custodial account during four time periods each year-referred to as offering periods" (Publix Asset Management Company, 2020, para. 3). An associate becomes eligible to purchase stock in this plan after 12 months of continuous employment with Publix (Publix Asset Management Company, 2020). Each associate is required to complete a purchase agreement form in order to purchase stock. As can be seen in Figure 4, the current stock price for Publix as of August 2020 is \$54.35 per share (Publix Stockholder, 2020).

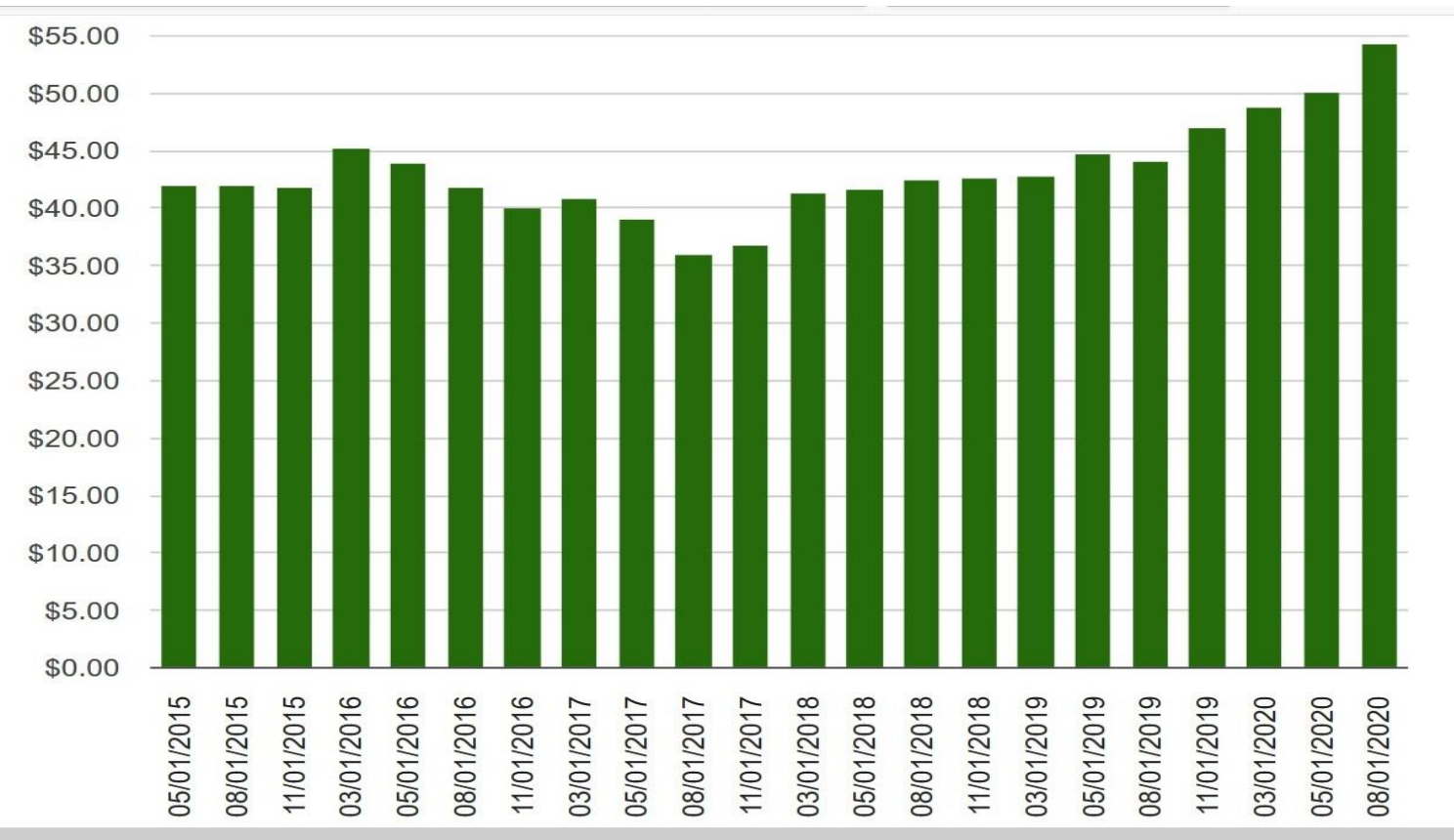

Figure 4. Publix Stock Status (October 2020)

(Source: www.publix.com)

Lastly, Publix believes in preparing their associates for their future. As part of the Publix SMART Plan, associates are given the opportunity to save for their retirement. This is 
achieved by associates committing pre-tax dollars to an account in which they will make direct payments. All associates gain eligibility into the plan once they have completed 6 months of continuous employment and they meet the 18 years of age requirement. All associates are entitled to contribute from 1-30\% of their pay each pay period (Publix Asset Management Company, 2020). The Publix board of directors decides on a matching contribution each year. The Board can contribute anywhere from 50 cents to a maximum of \$750 yearly to eligible associates (Publix Asset Management Company, 2020).

Ultimately, what makes Publix such a revered employer, is their unwavering commitment to their employees. Mr. Jenkins recognized that a company was only as successful as its employees, which is why Publix continues to thrive in the present market. Publix invests in its employees, and, as a result, employees continue to take honor in their work and offer exceptional customer service.

\section{Associate Voice Survey (AVS)}

One policy which stands out, with respect to Publix, is its Associate Voice Survey. Publix consistently validates to its associates that their voice matters. In the year 1997, Publix recorded an estimated 90,000 associates who completed the Associate Voice Survey (Mujtaba and Johnson, 2016) and this trend in hearing the voice of employees has continued over the past two decades. Due to the completion of the AVS, Publix came to comprehend that communication was at the top of associates list when it came to satisfaction with their employment. Associates also value customer service, loyalty, and positive co-worker attitude. As a result of the AVS, many stores take it upon themselves to create local teams that they deploy to address potential improvements to their stores. Mr. Jenkins once said that "we envision Publix as a world player. And there will be bumps in the road as we grow larger and spread further. I need each of you to help me uphold our mission to be the premier quality food retailer in the world" (Mujtaba and Johnson, 2016, p. 36). Statements such as the latter illustrate that Mr. Jenkins' legacy lives on today that Publix believes in its employees, and asserts the essentiality of employees to the future success of the company.

\section{Green Is More than Just the Color or Logo}

According to Hollenback and colleagues, "sustainability refers to the company's ability to meet its needs without sacrificing the ability of future generations to meet their needs... Organizations pursuing a sustainable strategy pursue the 'triple bottom line': economic, social and environmental benefits" (2019, p. 16). Publix is able to compete at the highest levels leveraging sustainability by incorporating cost-effective workflow methods, providing quality work experiences for its employees, engaging social efforts within the community, and delivering certain environmental benefits through various channels.

Publix is able to effectively provide a return to their shareholders while being environmentally conscious by several means. Publix conducts energy audits frequently to ensure that they are operating with the best efficiency possible. With the installation of solar panels within five of its locations, Publix is able to save money through utility bills, secure tax breaks by providing clean/reusable energy, and reduce its carbon footprint. In addition, 
Publix has also switched to LED lighting within their stores, as this cost-effective source of light saves electricity by $35 \%$. In terms of distribution, Publix has saved 12 million miles and more than 1.8 million gallons of diesel since 2007 by optimizing transportation routes and adjusting how products are loaded and sent. Oftentimes when companies think of the statement "environmentally friendly" they see this as a cost/burden, but Publix has been able to incorporate environmental strategies that ultimately save the company money while working in a socially responsible manner toward sustainability in all their operations.

Publix prides itself on being a company centered around its employees, as they recognize the significance of having employees that feel empowered and recognized. Every year, Publix distributes several rewards to acknowledge the dedication and integrity of their employees. Some of these awards include, the Mr. George Community Service Award and the Customer Service Excellence Award. In addition, Publix provides its employees considerable products and services, such as tuition reimbursement, health insurance, and Retirement Employee Stock Ownership, and 401(k) Plans. The benefits that Publix provides to its employees will ultimately lead to greater retention, improved employee performance, and cultivate employees that are proud of where they work.

Today, many companies are realizing the business potential through social responsibility possesses, as a company can increase their image with customers, tap into new markets, and attract/retain quality employees. With the previous statement in mind, Publix's social and environmental efforts have enhanced the relationships with the communities they serve and ensured economic stewardship for their stockholders. Some of Publix's social responsibility efforts include food donations to local organizations, which minimizes waste, and reusable shopping bags that support sustainability projects within the community such as planting trees that help clean waterways. Moreover, Publix demonstrates environmental consciousness through a plethora of means such as greenhouse gas reduction and water conservation. In 2015, Publix received an Innovation in Plastics Recycling Award from the American Chemistry Council (ACC) in recognition of their environmental efforts. A transcendent business today requires more than just exceptional products and services, but also efforts that reflect global, cultural, and social awareness.

\section{Open Door Policy}

Often times, when employees think about their company's open-door policy, they feel that these policies lack transparency and openness. Why are employees discouraged to utilize a policy meant to encourage collaboration and address concerns with management? The answer is simple. Many companies have these policies as mere formalities, as their organizational culture hinders the application of such an essential practice. According to Publix (2020, para. 3), "In 1930, with the start of his new company, Mr. George encouraged open communication with his associates." He once said, "If you want people to respect you or your company, you must first show respect for them." It is this very ideology that fosters a dynamic open-door policy. At Publix, employees are encouraged to share their perspectives and actively collaborate with managers to enhance their work experience and ultimately have their voices heard. Publix also incorporates continuous improvement efforts through the Associate Voice 
Survey (AVS) to instil transparency and openness throughout the company.

\section{Keeping Employees Safe during Covid-19 Pandemic}

As of the latter few months of the Covid-19 pandemic during 2020, the United States has had over 8.4 million positive cases of the coronavirus infections and 224,000 dead citizens as a result of it. At the same time period, on a global scale, we have seen over 41 million cases of positive Covid-19 infections and 1.2 million people dead. Some countries (i.e. Canada, New Zealand, Singapore, Vietnam, South Korea, etc.) and firms have done a great job of keeping everyone safe through a national strategy of testing, treating and tracing Covid-19 positive cases and their contacts, while a few others (such as the USA and Brazil) have relied on somewhat of an ad hoc or informal strategies with the hope of the infection simply going away (Korman and Mujtaba, 2020).

In the absence of a national masking strategy or a cohesive process of testing, treating and tracing positive infections by the U.S. government and state governors, many corporations have had to proactively act by requiring their employees and customers to wear a mask in their premises during this Covid-19 pandemic. As such, to keep their customers and employees safe, Publix was one of the first companies in the country to require masks, social distancing, and the enforcement of proper quarantine procedures for all their employees during this pandemic. Pretty soon, many other firms in Florida and around the United States followed Publix's example by requiring that their employees and customers wear masks.

Employee safety has always been a top priority for all Publix managers and employees as many of their departmental leaders have been certified professional food managers by the State of Florida. During the Covid-19 pandemic in 2020, Publix began requiring all employees and customers to wear face coverings while working or shopping. Publix officials mentioned that, "Throughout this pandemic, we've implemented a number of process changes in our stores to safeguard the health and well-being of the communities we serve" (Publix Action, 2020, para. 3). Publix officials went on to explain why face coverings are required while in their stores by saying,

Our efforts are conducted with guidance from the Centers for Disease Control and Prevention (CDC), as well as local and state agencies. The CDC recommends face coverings to help slow the spread of COVID-19. We have previously encouraged our customers to follow CDC guidance and have now implemented a face covering requirement in our stores to do our part and help protect our communities (Publix Action, 2020, para. 5).

Managers and employees enforce this on a case by case situation when a shopper is not wearing a mask. Of course, as per the Center for Disease Control (CDC) guidelines, the requirement of masks do not apply to young children or people with medical conditions who are not able to wear a face covering.

In regard to cleaning the store, carts and sanitization Publix employees are following the CDC guidelines. In his statement on March 12, 2020, Publix CEO Todd Jones outlined a few points about their cleaning and product availability. And, consumers are redirected to the 
CDC website. However, Jones states that Publix routine cleaning procedure already meets these standards but added that they have more disinfectants in response to this Covid-19 pandemic (Publix CEO, 2020). They have suspended food demonstrations until further notice. Jones also says that they are "working tirelessly" to bring products to the shelves and that some essential items have a new limit on how many can be purchased at one time. For examples, they limited the purchase of sanitizers and masks to just two per customer during the initial period of this pandemic when supply availability was lacking across the country.

On March 31, 2020, Sara DiNatale wrote an article for the Tampa bay times about Publix allowing employees to wear masks and gloves while working during the Covid-19 pandemic. Of course, it was stated that no cloth or reusable masks are allowed to be used and that workers are prohibited from wearing face coverings all together.

While Publix employees were required to wear masks and gloves for their personal comfort, it was heavily emphasized all official advice from public health organizations state that washing hands frequently, maintaining social distancing, and avoiding touching of the eyes, nose, and mouth are the most effective ways to prevent the spread of Covid-19. Overall, Publix had a list of precautions the store employees were taking to help curb this pandemic (Avanier, 2020). This year, in almost all stores at Publix, an employee greets people at the door and controls the flow of shoppers. They have placed taped arrows on the floor to follow a single direction while shopping. They did this to prevent shopping aisles from becoming overcrowded with people. It is a method to keep social distancing standards as recommended by the CDC. They are also making sure people who are waiting in line to check out, make returns or other uses at the service desk are standing at the 6 feet tape markers to keep up with proper social distancing guidelines. Another addition is that all cash register workers now have a Plexiglas barrier between them and customers. They have also heightened disinfection cleaning processes by focusing on high touch areas like pin pads, doors, drawer handles, computers, and phones. They have formalized a mandatory quarantine and paid 14 day leave for any associate that has tested positive for Covid-19. They have a notification system for any other employees to be made aware if anyone at their store has tested positive. Publix adjusted store hours to accommodate senior citizens and other customers in a safe manner; however, now toward the end of 2020, they have returned to their regular opening and closing times. During a shopping trip May 22, 2020 at a Publix store in Davie, Florida, the first author asked the cashier how the employees felt about being "essential workers" and being open during the Covid-19 pandemic when most others are under quarantine; she responded that, "I cannot speak for everyone, but I am certainly lucky to have a job where working is a pleasure and to be able to serve our customers amid this pandemic with proper safeguards in place." She seemed happy that her managers and corporate leaders had created a safe working environment for them where the fears of being infected by the coronavirus at work was dramatically reduced. When employees feel safe, they will be more productive and creative at work.

Other retailers have followed similar procedures and guidelines as Publix. For example, Walmart increased support for their staff by implementing an "Emergency leave policy and health services." Under these new guidelines they provided a 4 dollar a day telehealth 
services to their associates and their families. They are waving fees for some medical and behavioral services that include behavioral counselling (Walmart Supporting Associates, 2020). As the Covid-19 situation evolved, at one time, Walmart managers decided to begin taking the temperatures of their associates as they report to work in stores, clubs and facilities, as well as asking them some basic health screening questions. Any associate with a temperature of 100.0 degrees were paid for reporting to work and asked to return home and seek medical treatment as necessary. Of course, as per their policies and CDC guidelines, such associates will not be able to return to work until they were fever-free for at least three days after the required quarantine period. They continue to ask associates to look out for the normal symptoms of the virus (coughing, feeling achy, difficulty breathing) and never come to work when they do not feel well.

The Target Corporation also had their own Covid-19 Enhancements. They listed certain expectations when working and shopping in their stores. They had increased cleanliness, monitoring and metering guest access, masks were made available to the public and are required while shopping in their stores, and the 6 feet reminders for social distancing were posted all around their stores. Target managers focused on keeping the work environments safe by applying rigorous cleaning routines and regularly communicating updates on guidance from the CDC to their team members so they can stay informed and safe. Also, they provided all team members with face masks and gloves to wear at work and encouraged healthy hygiene habits as guided by the CDC.

During this Covid-19 pandemic, all these retailers and others in Florida were concerned about the physical, emotional, and financial wellbeing of their associates and customers. As such, just like Publix, they all began following the CDC guidelines. Of course, many non-retail tech firms like Google, Apple, Microsoft, and others have made excellent organizational structural decisions as they have been able to allow more of their employees and teams to work from home during this Covid-19 coronavirus to keep them safe, happy, and productive amid a stressful pandemic environment (Paul, 2020; Konopaske, Ivancevich \& Matteson, 2014).

\section{Implications and Recommendations}

While there needs to be a great level of critical analysis of all the previous content presented in this case study by future researchers and students, we can certainly draw some relevant implications and recommendations as best practices for current and future managers of retail firms. Of course, all firms and organizations want to get a good return from their investments in the training and development of their human capital, but some are not always successful in its achievement.

One of the most visible and pressing problems at the management level in companies is the failure to deliver the expected benefits from investments in equipment, training, and organization development inputs. One major roadblock to change is the need to obtain organizational buy-in, i.e., if the desired outcomes are to be achieved, there needs to be a commitment to change. At all levels, organizational change efforts face inertia. A major obstacle to corporate growth is managers' failure to change their attitude or behavior as 
rapidly as their business requires. Consequently, it is recommended that managers need to improve their skills by diagnosing opposition to change and determining suitable methods to overcome it. If businesses goals are to be realized and overcome resistance to change, people in the company must be educated about the benefits of such envisaged change. Employees are more likely to embrace change when they recognize its importance and implications, perceiving that the benefit outweighs the cost. Again, even if there is proactive education, the individual educating a team is equally important. The aforementioned roadblocks are likely to present themselves, if there is not enough trust between the person initiating the change and the team. Accordingly, the best change efforts must not only transmit a distinct and compelling image of the program as a first step, but, everybody in the company, regardless of level, must also understand and embrace that vision.

Strategic HRM is at the intersection of HRM and strategic management. It espouses HRM as a vital, integrated, and coherent approach, and develops that in line with the concept of strategic management (Boxall, 2007). Cultural sensitivity, inclusion, and understanding are essential for human resources managers as businesses globalize, expanding the mix of cultures, languages, and attitudes within companies. Important HR implications result from the need for expertise in managing crucial business activities, including recruitment, selection, compensation, and labor relations. Today, successful businesses require the flexibility to work and manage cross-culturally to succeed in the international marketplace. Although, HR is often the voice of a company's home office to the local workers, it should also be the voice of the local culture to the home office or headquarters.

Publix HR team strategically created and directed initiatives designed to improve the potential of all employees with the hope to enhance the company's ability to provide quality products and deliver premier customer service. Of course, human resource practitioners of all firms are responsible for ensuring that their organizations operate in a legal, humane, professional, and socially responsible manner, while driving revenues and meeting organizational goals. As mentioned before, human resource management (HRM) refers to the practices, policies, and systems that influence employees' behavior, attitudes, and performance (Noe, Hollenbeck, Gerhart, \& Wright, 2019). In alignment with the definition of HRM, Publix's organizational structure and human resource practices and policies have positively contributed to its successes and longevity.

In recent years, Publix, like other organizations, continues to deal with unyielding changes attributed to technological advancements, Covid-19 pandemic, altered consumer behaviors through online shopping, and political change. Therefore, the aforementioned challenges, faced by Publix, provide opportunities for improving sustainability, branding, and keeping HR practices aligned with inevitable changes in consumer behaviors, employee needs/demands, legislation, and technological shifts. "Technological advances, changes in the workforce or governmental regulations, globalization, and new competitors are among the many factors that require companies to change" (Noe, Hollenbeck, Gerhart, \& Wright, 2019, p. 23). The ability to handle social/economic change, engaging in responsible and ethical business practices, providing quality services and products, and satisfying the needs of stakeholders are relevant strategies to ensure sustainability. 


\section{$\Lambda$ Macrothink}

From a managerial perspective, it is Publix's responsibility to ensure that all locations and employees are properly equipped to work and function efficiently. Such strategic managerial attention, inclusion, and planning keeps the company running smoothly while also preventing layoffs during challenging times (Mujtaba and Senathip, 2020). Allocating funding for operational upgrades is essential to Publix's sustainability, success, performance, and efficiency, which will ultimately increase revenue. Of course, we now know that sustainability is about meeting one's own needs without sacrificing the ability of future generations to meet their needs in the years to come. When stakeholders are satisfied, revenue increases, and a business maintains its relevance. HR practitioners have the onus of ensuring employees perform efficiently and produce premier work. Publix has managed to survive, maintain its relevance, and thrive despite the societal changes, Covid-19 pandemic, and recessions that have occurred over the last few decades. However, it is imperative for Publix HR personnel to strategically set measurable goals and provide adequate feedback to both employees and senior management.

\section{Summary}

The human resource policies set forth by a firm provide structure, consistency, transparency, and direction amongst employees at all levels. These policies must be able to withstand cultural, economic, and technological changes to remain effective. Over time, Publix has been a trailblazer within its industry through the implementation of policies that put their employees and customers at the forefront of everything they do. Policies such as "Life Inspired" and "Associate Voice Survey" demonstrate Publix's commitment to its employees. Rather than merely looking to improve employee performance, Publix seeks to improve the quality of life of its employees. In addition, Publix provides employee development and psychological success that fosters the growth of exceptional employees who are not only happy, but also proud of where they work. Publix also places much resources, time and effort on social and environmental responsibilities through their measures to promote sustainability, which further enhances the reputation of the company.

When a customer walks inside of a Publix they feel welcomed as they are greeted by employees eager to assist them, while they shop for quality products that meet and/or exceed their expectations. It is no accident that Publix has received countless awards and recognitions for their customer service and satisfaction, involvement within the community, and being an exceptional place to work. When consumers and competitors think of Publix they think of the word "quality," as the organization checks off every box in terms of how to properly operate a business, but more specifically the utilization of evidence-based HR that provides strategic value that creates unrivalled employee/customer experiences.

\section{Acknowledgement}

The first author would like to acknowledge the work of all former graduate students at Nova Southeastern University who have provided relevant knowledge and research about human resource management practices at Publix and other retail outlets which are highlighted in this paper. 


\section{References}

Acosta, G. (2018, October). Publix Shakes Up executive ranks. Retail Leader. Retrieved from https://retailleader.com/publix-shakes-executive-ranks

Aragón-Sánchez, A., Barba-Aragón, I., \& Sanz-Valle, R. (2003). Effects of training on business results. International Journal of Human Resource Management, 14(6), 956-980.

Avanier, E. (Aril 9, 2020). News 4 Jax - Coronavirus: here are the changes you will see at Publix stores.

Link: https://www.news4jax.com/news/2020/04/10/coronavirus-here-are-the-changes-youll-see-atpublix-stores/

Blank, C. (2011, December 30). Publix's 'Sabor' Includes New Look. Retrieved September 28, 2020 from: https://www.supermarketnews.com/archive/publixs-sabor-includes-new-look

Boxall, P. (2007, January 30). The Strategic HRM Debate and the Resource-Based View of the Firm. Retrieved from https://onlinelibrary.wiley.com/doi/abs/10.1111/j.1748-8583.1996.tb00412.x

Christopher, M., Payne, A., \& Ballantyne, D. (1991). Relationship marketing: Bringing quality, customer service and marketing together. International Business Review, 4(4), 538-541. https://doi.org/10.1016/0969-5931(95)90007-1

Delapenha, C., Espinosa, C., Fabre, J., Lemon, P., Gibson, N., \& Mujtaba, B.G. (August 2020). The SAS Institute's Human Resources Practices in Diversity and Inclusion. Journal of Human Resource and Sustainability Studies, 8(3), 249-265. https://doi.org/10.4236/jhrss.2020.83014

Everitt, L. (2008, September 3). The Five Secrets of Publix Supermarkets' Success. Retrieved from https://www.cbsnews.com/news/the-five-secrets-of-publix-supermarkets-success/

GoodRx. (n.d.). Chantix Cost, Coupons, \& Savings. (2020). Retrieved from:https://www.goodrx.com/chantix

Great Place to Work: Publix Super Markets Inc. (2019). Retrieved October 24, 2019, from https://www.greatplacetowork.com/certified-company/1000405.

Haddon, H., \& Risso, L. (2017). Business News: Regional Grocery Stores Feel Squeeze Amid Upheaval. Wall Street Journal, August 14: B3.

Harrison, J. S., Owdom, M., Pitchford, D., Stratton, A., \& Warren, B. (2018, January). Publix Supermarkets, Inc. Retrieved from https://scholarship.richmond.edu/robins-case-network/19/

Konopaske, R., Ivancevich, J. M., \& Matteson, M. T. (2014). Organizational Behavior and Management. New York City: McGraw Hill Education.

Kritzer, A. (2016). Publix Sets Its Sights on Northern Virginia, metro D.C. area. Tampa Bay Business Journal, May $24 . \quad$ Retrieved from https://www.bizjournals.com/tampabay/blog/morning-edition/2016/03/publix-set-its-sights-o 
n-northernvirginiametro-d.html

Korman, K., \& Mujtaba, B. G. (August 2020). Corporate Responses to COVID-19 Layoffs in North America and the Role of Human Resources Departments. Reports on Global Health Research, $3(2)$,

$1-17$.

https://www.gavinpublishers.com/articles/review-article/Reports-on-Global-Health-Research/ corporate-responses-to-covid-19-layoffs-in-north-america-and-the-role-of-human-resources-d epartments

McFarlane, D. A., \& Cooper, T. V. (2009). An Analysis of Publix Super Markets Using VDM, Competitive Advantage, and SWOT Factors. Business Journal for Entrepreneurs, 3, 57.

McTaggart, J. (2007). Lakeland legacy. Progressive Grocer, 86(11), 18-24. Retrieved from http://search.ebscohost.com.ezproxylocal.library.nova.edu/login.aspx?direct=true \&db=buh\& $\mathrm{AN}=26529986 \&$ site $=$ ehost-live

Michael, C. (2017). The Employee Ownership Trust, an ESOP Alternative. Probate \& Property, 31(1), p.42. Retrieved from: https://www.academia.edu/36147959/The_Employee_Ownership_Trust_an_ESOP_Alternati ve

Mujtaba, B. G. (2014). Managerial Skills and Practices for Global Leadership. ILEAD Academy: Florida.

Mujtaba, B. G., \& Senathip, T. (2020). Layoffs and Downsizing Implications for the Leadership Role of Human Resources. Journal of Service Science and Management, 13(2), 209-228. https://doi.org/10.4236/jssm.2020.132014

Mujtaba, B. G., \& Johnson, W. (2016). Creating an Organizational Culture of Delightful Customer Intimacy at Publix Super Markets, Inc. International Journal of Marketing Practices, $3(2), 47-67$.

Mujtaba, B. G., \& Franklin, E. (2007). A retailer's steady growth strategy: Should Publix stay national or go global? Journal of Business Case Studies, 3(4), 33-42. https://doi.org/10.19030/jbcs.v3i4.4862

Noe, R. A., Hollenbeck, J. R., Gerhart, B., \& Wright, P. M. (2019). Human resource management: Gaining a competitive advantage (11th Ed.). New York, NY: McGraw-Hill Education.

Owens, C. (2019, January 23). Tech Data, Publix secure rankings among 'World's Most Admired Companies.' Retrieved from https://www.bizjournals.com/tampabay/news/2019/01/23/tech-data-publix-secure-rankings-a mong-fortune-s.html

Ozolina-Ozola, I. (2014). The Impact of Human Resource Management Practices on Employee Turnover. Procedia - Social and Behavioral Sciences, 156, 223-226.

Paul, K. (2020, July 27). The Guardian. Retrieved from The Guardian: https://www.theguardian.com/technology/2020/jul/27/google-employees-work-from-home-co 
ronavirus-pandemic

Publix. (2019). Nine Reasons to Work at Publix. Retrieved October 24, 2019, from https://corporate.publix.com/careers/why-publix/nine-reasons-to-work-at-publix\#targetText= Excellent\%20Benefits,on\%20numerous\%20products\%20and\%20servicesPublix actions on Covid-19 (July 2020). Publix precautions during the COVID-19 pandemic. Link: https://ww4.publix.com/faq/coronavirus

Publix CEO (2020). A Message about Coronavirus from Publix CEO Todd Jones. Link: http://corporate.publix.com/about-publix/newsroom/news-releases/covid-19-message-from-c eo

Publix Facts and Figures (2020). Link: http://corporate.publix.com/about-publix/company-overview/facts-figures

Publix Facts (2020). Best Practices at Publix Super Markets. Research presented in HRM 5310 course at Nova Southeastern University's College of Business and Entrepreneurship during 2019-2020.

Publix Leaders Recognized with Most Prestigious Awards. Publix Supermarkets (2020, February 12). Retrieved from https://apnews.com/8e81cae04b8a44f58e3bc2ec82c09eb9

Publix Power (2014). The Power of Publix: Florida's Grocery Darling Takes Over the South. Retrieved from https://www.enterpriseflorida.com/wp-content/uploads/Publix-Floridas-Foremost-v1.pdfPubli x Stockholder (2020). Publix Stock Price. Retrieved from: https://www.publixstockholder.com/

Publix Supermarkets. (n.d.). Publix History. (2020). Retrieved from https://corporate.publix.com/about-publix/culture/history

Publix Supermarkets. (n.d). Publix Human Resources. (2020). Retrieved from https://corporate.publix.com/careers/support-areas/corporate/departments/human-resources

Publix Supermarket. (n.d). Recognition and Awards. (2020). Retrieved from https://sustainability.publix.com/customer-service-desk/recognition-and-achievements/

Publix Supermarket Committed to Diversity. (2020). Retrieved on September 28, 2020 from: http://corporate.publix.com/about-publix/culture/committed-to-diversity

Rose, W. (2019). Publix Employee Benefits Review: Are Their Careers Worth It? Retrieved from https://futurefuel.io/employee-benefits/publix-careers/

Tampa Bay Times (March 31, 2020). Publix Now Allows Certain Employees to Wear Masks and Gloves. Link: https://www.tampabay.com/news/health/2020/03/31/publix-now-allows-certain-employees-to -wear-masks-and-gloves/

Tessema, M. T., Ready, K. J., \& Embaye, A. B. (2013). The Effects of Employee Recognition, Pay, and Benefits on Job Satisfaction: Cross Country Evidence. Journal of Business and 
Economics, 4(1), 1-12.

Testa, M. R. (2001). Organizational Commitment, Job Satisfaction, and Effort in the Service Environment. Journal of Psychology, 135(2), 226-236. https://doi.org/10.1080/00223980109603693

Tkaczyk, C. (2016, March 3). My Five Days of 'Bleeding Green'. Retrieved October 24, 2019, from https://fortune.com/longform/publix-best-companies/

Tran, C. T. H., Tran, H. T. M., Nguyen, H. T. N., Mach, D. N., Phan, H. S. P., \& Mujtaba, B. G. (2020). Stress Management in the Modern Workplace and the Role of Human Resource Professionals. Business Ethics and Leadership, 4(2), 26-40. https://doi.org/10.21272/bel.4(2).26-40.2020

Walmart Supporting Associates (2020). Link: https://corporate.walmart.com/supporting-our-associates

\section{Copyright Disclaimer}

Copyright for this article is retained by the author(s), with first publication rights granted to the journal.

This is an open-access article distributed under the terms and conditions of the Creative Commons Attribution license (http://creativecommons.org/licenses/by/4.0/). 